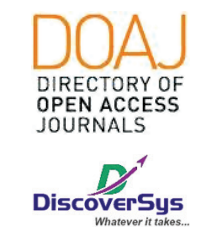

Published by DiscoverSys

\section{Evaluasi keberhasilan pengisian saluran akar dengan sediaan zinc oxide eugenol dan campuran calcium hydroxide dengan pasta iodoform}

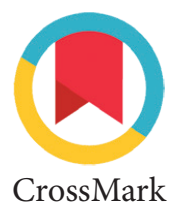

\author{
Luh Wayan Ayu Rahaswanti
}

\title{
ABSTRACT
}

Aim: the aim of this study was to investigate the succesful rate between Zinc Oxide Eugenol and Calcium Hydroxide with lodoform Paste as root canal sealer for necrotic primary teeth.

Method: pulpectomy procedures were conducted on 16 maxilary anterior teeth and for the obturation step, they were devided into two groups consist of 8 teeth. The first group of teeth were obturated with Zinc 0xide Eugenol sealer and the second group were obturated with Calcium Hydroxide with lodoform Paste sealer. The data was taken on one month, two months, and three months after the treatment and then analized with Fisher's Exact Test.

Result: the result shows that there is no significant succesful rate between Zinc 0xide Eugenol and Calcium Hydroxide with lodoform Paste as root canal sealer for necrotic primary teeth.

Conclusion: the conclusion of this study is that both of Zinc Oxide Eugenol and Calcium Hydroxide with lodoform Paste have similar efficacy in treating necrotic primary teeth.

Keywords: Endodontic, Zinc Oxide Eugenol, ZnOE, Calcium Hydroxide, $\mathrm{Ca}(\mathrm{OH})_{2}$, lodoform Paste, primary teeth, necrotic pulp Cite This Article: Rahaswanti LWA. 2017. Evaluasi keberhasilan pengisian saluran akar dengan sediaan zinc oxide eugenol dan campuran calcium hydroxide dengan pasta iodoform. Intisari Sains Medis 8(1): 1-7. D0l: 10.1556/ism.v8i1.1

ABSTRAK

Pendahuluan: Sediaan campuran Zinc Oxide dan Eugenol merupakan bahan pengisi saluran akar yang pertama kali direkomendasikan bagi pengisian saluran akar geligi desidui, seperti yang telah dilaporkan oleh Sweet pada tahun 1930. Selanjutnya, sediaan campuran Calcium Hydroxide dan pasta iodoform yang dipercaya merupakan sediaan yang paling mendekati ideal sebagai bahan pengisi saluran akar geligi desidui. Tujuan penelitian ini adalah membandingkan efektifitas pasta Zinc 0xide dan Eugenol dengan campuran Calcium Hydroxide dan pasta iodoform sebagai bahan pengisi saluran akar bagi geligi desidui yang nekrosis. Metode: perawatan pulpektomi dilakukan pada 16 buah gigi desidui anterior yang dibagi menjadi 2 kelompok perlakuan, yaitu 8 gigi sebagai kelompok pengisian saluran akar dengan pasta campuran Calcium Hydroxide dengan pasta iodoform (Metapex ${ }^{\circledast}$, Meta, Korea) dan 8 gigi sebagai kelompok pengisian saluran akar dengan Campuran semen Zinc Oxide (Kalzino ${ }^{\circledR}$, Densply, Jerman) dan cairan eugenol (Eugenol, Prevest DenPro Limited, India). Data hasil perbandingan keberhasilan perawatan secara menyeluruh dari 2 kelompok sampel dianalisa dengan Fisher's Exact Test.

Hasil: hasil uji klinis pada penelitian ini menunjukkan bahwa pengisian saluran akar gigi desidui dengan pasta campuran Calcium Hydroxide dengan pasta iodoform dan sediaan Zinc Oxide dan Eugenol tidak menunjukkan perbedaan yang bermakna.

Kesimpulan: kesimpulan dari penelitian ini adalah sediaan campuran Calcium Hydroxide dengan pasta iodoform maupun Zinc Oxide Eugenol merupakan bahan-bahan yang memiliki potensi baik sebagai bahan pengisi saluran akar gigi desidui dengan diagnosa nekrosis pulpa.

Kata kunci: Endodontik, Zinc Oxide Eugenol, ZnOE, Calcium Hydroxide, $\mathrm{Ca}(\mathrm{OH})_{2}$, Pasta lodoform, gigi desidui, nekrosis pulpa.

Program Studi Pendidikan Dokter Gigi Fakultas Kedokteran Universitas Udayana

Correspondence to: Luh Wayan Ayu Rahaswanti, Program Studi Pendidikan Dokter Gigi Fakultas Kedokteran Universitas Udayana

Diterima: 12 Desember 2016 Disetujui: 17 Desember 2016 Diterbitkan: 02 Januari 2017

\section{PENDAHULUAN}

Mempertahankan geligi desidui yang pulpanya mengalami keradangan akibat karies yang dalam maupun trauma merupakan suatu masalah besar dalam merawat gigi anak-anak. ${ }^{1}$ Untuk itu, perawatan saluran akar telah dilakukan sejak awal tahun 1937 sebagai cara / metode untuk mempertahankan geligi dalam kondisi steril, sehingga tidak mengalami tanggal. ${ }^{2}$

Tujuan dari perawatan pulpa yang dilakukan oleh dokter gigi adalah berhasilnya perawatan pada pulpa yang menderita karies, sehingga gigi tersebut dapat tetap berada dalam rongga mulut dalam keadaan non patologis dan sehat, sehingga geligi desidui dapat dipertahankan tidak hanya untuk memenuhi kebutuhan pengunyahan, melainkan juga sebagai space maintainer bagi geligi permanen. ${ }^{1}$

Ada beberapa teknik dalam merawat geligi desidui yang mengalami karies, yaitu: indirect pulp capping, direct pulp capping, partial pulpotomy, pulpotomy, dan pulpectomy. Berbagai obat-obatan 
dan bahan-bahan juga telah digunakan untuk menyertai teknik-teknik perawatan tersebut, dan berbagai tingkat kesuksesan perawatan telah dilaporkan. ${ }^{1}$

Sediaan campuran Zinc Oxide dan Eugenol merupakan bahan pengisi saluran akar yang pertama kali direkomendasikan bagi pengisian saluran akar geligi desidui, seperti yang telah dilaporkan oleh Sweet pada tahun 1930. Sejak saat itu, banyak peneliti melaporkan tingkat keberhasilan yang sedang sampai tinggi mengenai penggunaan pasta Zinc Oxide dan Eugenol sebagai bahan pengisi saluran akar geligi desidui yang mengalami infeksi kronis. $^{2}$

Akhir-akhir ini, suatu jenis pasta campuran telah beredar di pasaran sebagai bahan pengisian saluran akar. Bahan tersebut merupakan campuran Calcium Hydroxide dan pasta iodoform yang dipercaya merupakan sediaan yang paling mendekati ideal sebagai pengisi saluran akar geligi desidui. $^{2}$

Pada penelitian ini, peneliti ingin membandingkan efektifitas pasta Zinc Oxide dan Eugenol dengan campuran Calcium Hydroxide dan pasta iodoform sebagai bahan pengisi saluran akar bagi geligi desidui yang nekrosis.

\section{BAHAN DAN METODE BAHAN}

Penelitian ini dilakukan dengan bantuan alat-alat diagnostik kedokteran gigi, alat-alat endodontik, dan alat-alat penambalan. Untuk bahan-bahan pengisian saluran akar yang akan dibandingkan, digunakan pasta campuran Calcium Hydroxide dengan pasta iodoform (Metapex ${ }^{\oplus}$, Meta, Korea) dan Campuran semen Zinc Oxide (Kalzinol', Densply, Jerman) dengan cairan eugenol (Eugenol, Prevest DenPro Limited, India), cairan irigasi Sodium Hypochloride (NaOCL) 1\%, bahan tambalan tetap Glass Ionomer Cement (Fuji II, GC, Japan).

\section{METODE}

Uji klinis dalam penelitian ini dilakukan dalam rentang waktu 6 bulan dengan rancangan beforeafter two group design dan cara pengambilan sampel pada penelitian ini adalah Selective Random Sampling.

Kriteria inklusi untuk sampel penelitian ini meliputi:

1. Gigi yang dijadikan sampel penelitian adalah gigi dengan diagnosa gangren pulpa.

2. Gigi yang dijadikan sampel penelitian memenuhi kriteria indikasi perawatan pulpektomi, yaitu:
- Dari pemeriksaan klinis dan radiografis didiagnosa gigi non vital/gangren pulpa.

- Adanya abses atau fistula

- Gigi masih dapat direstorasi setelah dilakukan perawatan saluran akar.

3. Pasien kooperatif.

4. Pasien tidak memiliki kelainan sistemik atau sedang menjalani terapi obat-obatan yang berhubungan dengan kondisi sistemiknya.

5. Orang tua pasien telah menandatangani lembar persetujuan bersedia berperan serta dalam penelitian ini dan datang pada waktu kontrol untuk diobservasi.

Kriteria yang dicatat pada pemeriksaan klinis sebelum perawatan meliputi: ${ }^{3}$

- Ada/tidaknya pembengkakan pada gingiva.

- Ada/tidaknya abses atau fistula.

- Ada tidaknya kegoyangan gigi yang abnormal.

- Ada/tidalnya nyeri saat diberi tekanan ringan.

- Ada/tidaknya rasa nyeri spontan.

Sedangkan kriteria yang dipantau pada pemeriksaan radiografis meliputi: ${ }^{3}$

- Keberadaan resorpsi eksternal akar gigi desidui yang akan dirawat.

- Keberadaan resorpsi internal akar yang akan dirawat.

- Keberadaan radiolusensi di bagian furkasi.

- Keberadaan radiolusensi periapikal.

Perawatan pulpektomi dilakukan pada 16 buah gigi desidui anterior yang dibagi menjadi 2 kelompok perlakuan, yaitu 8 gigi sebagai kelompok pengisian saluran akar dengan pasta campuran Calcium Hydroxide dengan pasta iodoform (Metapex ${ }^{\oplus}$, Meta, Korea) dan 8 gigi sebagai kelompok pengisian saluran akar dengan Campuran semen Zinc Oxide (Kalzinol ${ }^{\circ}$, Densply, Jerman) dan cairan eugenol (Eugenol, Prevest DenPro Limited, India). Instruksi kontrol adalah 1, 2, dan 3 bulan pasca perawatan, dimana pemeriksaan dan pencatatan data yang dilakukan sama dengan pemeriksaan-pemeriksaan sebelum perawatan, yaitu pemeriksaan klinis dan radiografis.

Kriteria keberhasilan secara klinis meliputi: penderita yang datang dengan atau tanpa gejala awal ada rasa sakit pada perkusi, fistula, pembengkakan intra oral, dan keluhan saat pertama datang, tanda dan gejala awal tersebut berkurang atau malah hilang sama sekali dalam masa observasi (1, 2, dan 3 bulan). Sedangkan kriteria keberhasilan perawatan secara radiografis meliputi: penderita dengan diagnosa gangren pulpa yang disertai radiolusensi periapikal 
pada pemeriksaan radiografis awal mengalami penurunan ukuran radiolusensi tersebut selama masa observasi (3 bulan pasca perawatan). Sedangkan penderita dengan diagnosa gangren pulpa tanpa disertai radiolusensi periapikal pada saat pemeriksaan radiografis awal, tidak menunjukkan gambaran radiolusensi baru dalam masa observasi (1, 2, dan 3 bulan pasca perawatan). ${ }^{2}$

Data hasil perbandingan keberhasilan perawatan secara menyeluruh dari 2 kelompok sampel dianalisa dengan Fisher's Exact Test.

Tabel 1 Analisa uji Fisher's Exact bagi kategori sakit pada perkusi visit 1, kontrol 1 bulan, kontrol 2 bulan, dan kontrol 3 bulan antara kelompok uji Zinc Oxide Eugenol dan kelompok uji campuran Calsium Hydroxide dengan pasta iodoform

\begin{tabular}{llccccc}
\hline \multicolumn{5}{c}{ Kelompok Uji } & & \\
\cline { 2 - 5 } Visit ke & $\begin{array}{c}\text { Sakit } \\
\text { pada } \\
\text { perkusi }\end{array}$ & ZOE & $\begin{array}{c}\text { Ca(OH) } \\
\text { + pasta } \\
\text { iodoform }\end{array}$ & Total & $\begin{array}{c}\text { Chi- } \\
\text { square }\end{array}$ & p-value \\
\hline 1 & Tidak ada & $6(42,9 \%)$ & $8(51,7 \%)$ & $14(100 \%)$ & 0,571 & 0,467 \\
& Ada & $2(100 \%)$ & $0(0 \%)$ & $2(100 \%)$ & & \\
Kontrol & Total & $8(50 \%)$ & $8(50 \%)$ & $16(100 \%)$ & & \\
1 bulan & Tidak ada & $8(50 \%)$ & $8(50 \%)$ & $16(100 \%)$ & & - \\
Kontrol & Tidak ada & $8(50 \%)$ & $8(50 \%)$ & $16(100 \%)$ & & - \\
Konlan & Total & $8(50 \%)$ & $8(50 \%)$ & $16(100 \%)$ & - & - \\
3 bulan & Tidak ada & $8(50 \%)$ & $8(50 \%)$ & $16(100 \%)$ & - & - \\
\hline
\end{tabular}

Tabel 2 Analisa uji Fisher's Exact bagi kategori adanya fistel pada visit 1, kontrol 1 bulan, kontrol 2 bulan, dan kontrol 3 bulan antara kelompok uji Zinc Oxide Eugenol dan kelompok uji campuran Calsium Hydroxide dengan pasta iodoform

\begin{tabular}{llccccc}
\hline \multirow{2}{*}{ Visit ke } & \multicolumn{5}{c}{ Kelompok Uji } & \multicolumn{3}{c}{ Ca(OH) } \\
+ pasta \\
\cline { 2 - 5 } 1 & Tidak ada & $7(50 \%)$ & $7(50 \%)$ & $14(100 \%)$ & 0 & 1 \\
& Ada & $1(50 \%)$ & $1(50 \%)$ & $2(100 \%)$ & & \\
& Total & $8(50 \%)$ & $8(50 \%)$ & $16(100 \%)$ & & \\
Kontrol & Tidak ada & $7(50 \%)$ & $7(50 \%)$ & $14(100 \%)$ & 0 & 1 \\
1 bulan & Ada & $1(50 \%)$ & $1(50 \%)$ & $2(100 \%)$ & & \\
& Total & $8(50 \%)$ & $8(50 \%)$ & $16(100 \%)$ & & \\
Kontrol & Tidak ada & $7(46,7 \%)$ & $8(53,3 \%)$ & $15(100 \%)$ & 1,067 & 0,467 \\
2 bulan & Ada & $1(100 \%)$ & $0(0 \%)$ & $1(100 \%)$ & & \\
& Total & $8(50 \%)$ & $8(50 \%)$ & $16(100 \%)$ & & \\
Kontrol & Tidak ada & $8(50 \%)$ & $8(50 \%)$ & $16(100 \%)$ & & \\
3 bulan & Total & $8(50 \%)$ & $8(50 \%)$ & $16(100 \%)$ & & \\
\hline
\end{tabular}

\section{HASIL}

Dari tabel 1 kategori sakit pada perkusi, terlihat bahwa pada visit 1 diperoleh $\mathrm{p}=0.467$, dimana nilai $\mathrm{p}>0.05$ menunjukkan bahwa tidak ada perbedaan yang bermakna dari kedua kelompok uji. Sementara pada kontrol 1 bulan, 2 bulan, dan 3 bulan tidak ada perubahan jumlah, sehingga tidak dapat dilakukan uji statistik.

Tabel 2 kategori adanya fistel, menunjukkan bahwa pada visit 1, kontrol 1 bulan, dan kontrol 2 bulan diperoleh $\mathrm{p}=0.467$, dimana nilai $\mathrm{p}>0.05$ mengandung makna tidak ada perbedaan yang bermakna dari kedua kelompok uji. Sementara pada kontrol 3 bulan tidak ada perubahan jumlah, sehingga tidak dapat dilakukan uji statistik.

Dari tabel 3 kategori bengkak intra oral, terlihat bahwa pada visit 1, kontrol 1 bulan, dan kontrol 2 bulan diperoleh $\mathrm{p}=0.467$, dimana nilai $\mathrm{p}>0.05$ bermakna tidak ada perbedaan yang bermakna dari kedua kelompok uji. Sementara pada kontrol 3 bulan tidak ada perubahan jumlah, sehingga tidak dapat dilakukan uji statistik.

Pada tabel 4 kategori adanya radiolusensi periapikal, terlihat bahwa pada visit 1 , kontrol 1 bulan, kontrol 2 bulan, dan kontrol 3 bulan diperoleh $\mathrm{p}=$ 0.467, dimana nilai $\mathrm{p}>0.05$ menunjukkan tidak ada perbedaan yang bermakna dari kedua kelompok uji.

Dari tabel 5 kategori adanya keluhan nyeri, terlihat bahwa pada visit 1, kontrol 1 bulan, dan kontrol 2 bulan diperoleh $\mathrm{p}=0.467$, dimana nilai $\mathrm{p}>0.05$ menunjukkan tidak ada perbedaan yang bermakna dari kedua kelompok uji. Sementara pada kontrol 3 bulan tidak ada perubahan jumlah, sehingga tidak dapat dilakukan uji statistik.

\section{DISKUSI}

Pulpektomi merupakan perawatan saluran akar yg melibatkan pengambilan seluruh jaringan pulpa gigi, termasuk jaringan koronal dan saluran akar. ${ }^{1}$ Alasan utama pemilihan jenis perawatan ini adalah dengan mempertimbangkan resiko-resiko yg mungkin akan dialami oleh benih gigi pengganti gigi desidui yang dirawat.

Tujuan dari perawatan adalah berhasilnya perawatan bagi pulpa yang terkena karies, sehingga gigi-gigi tersebut dapat tetap berada dalam rongga mulut dalam keadaan non patologis, kondisinya sehat, dan memenuhi kriteria sebagai komponen geligi desidui, dimana geligi desidui dipertahankan tidak hanya untuk memenuhi kebutuhan pengunyahan, melainkan juga sebagai space maintainer bagi geligi permanen, dan dapat mencegah kebiasaan-kebiasaan yang tidak diinginkan seperti mendorong lidah dan untuk keperluan fonetik.,4 Pulpektomi juga bertujuan untuk menghilangkan 
Tabel 3 Analisa uji Fisher's Exact bagi kategori adanya bengkak intra oral pada visit 1, kontrol 1 bulan, kontrol 2 bulan, dan kontrol 3 bulan antara kelompok uji Zinc Oxide Eugenol dan kelompok uji campuran Calsium Hydroxide dengan pasta iodoform

\begin{tabular}{|c|c|c|c|c|c|c|}
\hline \multirow[b]{2}{*}{ Visit ke } & \multicolumn{3}{|c|}{ Kelompok Uji } & \multirow[b]{2}{*}{ Total } & \multirow[b]{2}{*}{$\begin{array}{c}\text { Chi- } \\
\text { square }\end{array}$} & \multirow[b]{2}{*}{ p-value } \\
\hline & $\begin{array}{l}\text { Bengkak } \\
\text { intra oral }\end{array}$ & ZOE & $\begin{array}{c}\mathrm{Ca}(\mathrm{OH})_{2} \\
+ \text { pasta } \\
\text { iodoform }\end{array}$ & & & \\
\hline \multirow[t]{3}{*}{1} & Tidak ada & $6(46,2 \%)$ & $7(53,8 \%)$ & $13(100 \%)$ & 0,41 & 1 \\
\hline & Ada & $1(33,3 \%)$ & $2(66,7 \%)$ & $3(100 \%)$ & & \\
\hline & Total & $7(43,8 \%)$ & $9(56,2 \%)$ & $16(100 \%)$ & & \\
\hline \multirow{3}{*}{$\begin{array}{l}\text { Kontrol } \\
1 \text { bulan }\end{array}$} & Tidak ada & $8(53,3 \%)$ & $7(46,7 \%)$ & $15(100 \%)$ & 1,067 & 1 \\
\hline & Ada & $0(0 \%)$ & $1(100 \%)$ & $1(100 \%)$ & & \\
\hline & Total & $8(50 \%)$ & $8(50 \%)$ & $16(100 \%)$ & & \\
\hline \multirow{3}{*}{$\begin{array}{l}\text { Kontrol } \\
2 \text { bulan }\end{array}$} & Tidak ada & $7(46,7 \%)$ & $8(53,3 \%)$ & $15(100 \%)$ & 1,067 & 0,467 \\
\hline & Ada & $1(100 \%)$ & $0(0 \%)$ & $1(100 \%)$ & & \\
\hline & Total & $8(50 \%)$ & $8(50 \%)$ & $16(100 \%)$ & & \\
\hline \multirow{2}{*}{$\begin{array}{l}\text { Kontrol } 3 \\
\text { bulan }\end{array}$} & Tidak ada & $8(50 \%)$ & $8(50 \%)$ & $16(100 \%)$ & - & - \\
\hline & Total & $8(50 \%)$ & $8(50 \%)$ & $16(100 \%)$ & & \\
\hline
\end{tabular}

Tabel 4 Analisa uji Fisher's Exact bagi kategori adanya radiolusensi periapikal pada pemeriksaan rontgen pada visit 1, kontrol 1 bulan, kontrol 2 bulan, dan kontrol 3 bulan antara kelompok uji Zinc Oxide Eugenol dan kelompok uji campuran Calsium Hydroxide dengan pasta iodoform

Kelompok Uji

\begin{tabular}{|c|c|c|c|c|c|c|}
\hline \multirow[b]{2}{*}{ Visit ke } & \multicolumn{3}{|c|}{ Kelompok Uji } & \multirow[b]{2}{*}{ Total } & \multirow[b]{2}{*}{$\begin{array}{c}\text { Chi- } \\
\text { square }\end{array}$} & \multirow[b]{2}{*}{ p-value } \\
\hline & $\begin{array}{c}\text { Radiolusensi } \\
\text { periapikal } \\
\text { pada } \\
\text { pemeriksaan } \\
\text { rontgen }\end{array}$ & ZOE & $\begin{array}{c}\mathrm{Ca}(\mathrm{OH})_{2} \\
+ \text { pasta } \\
\text { iodoform }\end{array}$ & & & \\
\hline \multirow[t]{3}{*}{1} & Tidak ada & $6(50 \%)$ & $6(50 \%)$ & $12(100 \%)$ & 0 & 1 \\
\hline & Ada & $2(50 \%)$ & $2(50 \%)$ & $4(100 \%)$ & & \\
\hline & Total & $8(50 \%)$ & $8(50 \%)$ & $16(100 \%)$ & & \\
\hline \multirow{3}{*}{$\begin{array}{l}\text { Kontrol } \\
1 \text { bulan }\end{array}$} & Tidak ada & $6(50 \%)$ & $6(50 \%)$ & $12(100 \%)$ & 0 & 1 \\
\hline & Ada & $2(50 \%)$ & $2(50 \%)$ & $4(100 \%)$ & & \\
\hline & Total & $8(50 \%)$ & $8(50 \%)$ & $16(100 \%)$ & & \\
\hline \multirow{3}{*}{$\begin{array}{l}\text { Kontrol } \\
2 \text { bulan }\end{array}$} & Tidak ada & $6(46,2 \%)$ & $7(53,8 \%)$ & $13(100 \%)$ & 0,41 & 1 \\
\hline & Ada & $2(66,7 \%)$ & $1(33,3 \%)$ & $3(100 \%)$ & & \\
\hline & Total & $8(50 \%)$ & $8(50 \%)$ & $16(100 \%)$ & & \\
\hline \multirow{3}{*}{$\begin{array}{l}\text { Kontrol } \\
3 \text { bulan }\end{array}$} & Tidak ada & $6(50 \%)$ & $6(50 \%)$ & $12(100 \%)$ & 2,286 & 0,467 \\
\hline & Ada & $2(100 \%)$ & $0(0 \%)$ & $2(100 \%)$ & & \\
\hline & Total & $8(50 \%)$ & $8(50 \%)$ & $16(100 \%)$ & & \\
\hline
\end{tabular}

infeksi sehingga gigi desidui dapat berfungsi secara normal sampai waktunya tanggal secara normal, tanpa membahayakan geligi permanen penggantinya atau kesehatan anak secara umum. ${ }^{3}$

Bahan pengisi saluran akar gigi desidui idealnya harus memenuhi syarat-syarat sebagai berikut: ${ }^{2,4,5,6,7}$
1. Kecepatan resorpsi bahan sama dengan kecepatan resorpsi akar gigi desidui.

2. Tidak membahayakan jaringan periapikal dan benih gigi permanen penggantinya.

3. Dapat diresorbsi bila terjadi kelebihan pengisian.

4. Besifat antiseptik.

5. Proses pengisian saluran akar mudah dan memiliki perlekatan yang baik dengan dinding saluran akar.

6. Tidak memiliki kemungkinan untuk mengkerut/ menyusut.

7. Dapat diambil dengan mudah bila diperlukan.

8. Bersifat radiopaque.

9. Tidak merubah warna gigi yang dirawat.

10. Tidak menghasilkan massa yang keras sehingga dapat melukai gigi pengganti dalam proses erupsinya.

11. Bersifat bioaktif pada proses penyembuhan.

Zinc Oxide Eugenol merupakan bahan yang paling umum digunakan dalam pengisian saluran akar pada geligi desidui. Keuntungan dan kerugian pemakaian bahan ini adalah sebagai berikut:

\section{A. Keuntungan: ${ }^{4}$}

1. Secara umum tidak berbahaya.

2. Bersifat antiseptik.

3. Memiliki sifat analgesic ringan.

4. Memiliki perlekatan yang baik dengan dinding saluran akar.

5. Bersifat radiopaque.

6. Tidak menyebabkan diskolorasi pada gigi yang dirawat.

\section{B. Kerugian:2,3,4,5,6,8}

1. Adanya resiko dapat melukai benih gigi permanen pengganti yang sedang berada dalam proses erupsi akibat kekerasan bahan pengisi ini.

2. Hanya memiliki spektrum anti bakteri yang kecil.

3. Aplikasi bahan sulit sehingga sering terjadi kekurangan pengisian.

4. Adanya perbedaan kecepatan resorpsi bahan pengisi dengan akar geligi desidui yang dirawat, dimana akar geligi desidui resorpsinya lebih cepat daripada pasta Zinc Oxide Eugenol ini, sehingga partikel pasta akan tertinggal dalam tulang alveolar saat akar sudah teresorpsi. hal tersebut dapat mengganggu erupsi geligi permanen pengganti.

5. Bila terjadi kelebihan pengisian saluran akar, menimbulkan reaksi tubuh yang tidak diinginkan seperti misalnya terjadi 
Tabel 5 Analisa uji Fisher's Exact bagi kategori adanya keluhan nyeri pada visit 1, kontrol 1 bulan, kontrol 2 bulan, dan kontrol 3 bulan antara kelompok uji Zinc Oxide Eugenol dan kelompok uji campuran Calsium Hydroxide dengan pasta iodoform

\begin{tabular}{|c|c|c|c|c|c|c|}
\hline \multirow[b]{2}{*}{ Visit ke } & \multicolumn{3}{|c|}{ Kelompok Uji } & \multirow[b]{2}{*}{ Total } & \multirow[b]{2}{*}{$\begin{array}{c}\text { Chi- } \\
\text { square }\end{array}$} & \multirow[b]{2}{*}{ p-value } \\
\hline & $\begin{array}{c}\text { Keluhan } \\
\text { nyeri }\end{array}$ & ZOE & $\begin{array}{c}\mathrm{Ca}(\mathrm{OH})_{2} \\
+ \text { pasta } \\
\text { iodoform }\end{array}$ & & & \\
\hline \multirow[t]{3}{*}{1} & Tidak ada & $6(50 \%)$ & $6(50 \%)$ & $12(100 \%)$ & 0 & 1 \\
\hline & Ada & $2(50 \%)$ & $2(50 \%)$ & $4(100 \%)$ & & \\
\hline & Total & $8(50 \%)$ & $8(50 \%)$ & $16(100 \%)$ & & \\
\hline \multirow{3}{*}{$\begin{array}{l}\text { Kontrol } \\
1 \text { bulan }\end{array}$} & Tidak ada & $7(53,8 \%)$ & $6(46,2 \%)$ & $13(100 \%)$ & 0,41 & 1 \\
\hline & Ada & $1(33,3 \%)$ & $2(66,7 \%)$ & $3(100 \%)$ & & \\
\hline & Total & $8(50 \%)$ & $8(50 \%)$ & $16(100 \%)$ & & \\
\hline \multirow{3}{*}{$\begin{array}{l}\text { Kontrol } \\
2 \text { bulan }\end{array}$} & Tidak ada & $7(46,7 \%)$ & $8(53,3 \%)$ & $15(100 \%)$ & 1,067 & 1 \\
\hline & Ada & $1(100 \%)$ & $0(0 \%)$ & $1(100 \%)$ & & \\
\hline & Total & $8(50 \%)$ & $8(50 \%)$ & $16(100 \%)$ & & \\
\hline \multirow{2}{*}{$\begin{array}{l}\text { Kontrol } \\
3 \text { bulan }\end{array}$} & Tidak ada & $8(50 \%)$ & $8(50 \%)$ & $16(100 \%)$ & - & - \\
\hline & Total & $8(50 \%)$ & $8(50 \%)$ & $16(100 \%)$ & & \\
\hline
\end{tabular}

keradangan. Selain itu kandungan bahan eugenol juga dapat merusak sel.

6. Zinc Oxide eugenol dapat mengiritasi jaringan periapikal dan dapat mengakibatkan nekrosis pada tulang dan sementum.

7. Dapat menimbulkan sitotoksik bila terjadi kontak dengan jaringan yang masih vital.

Adapun keuntungan dan kerugian dari penggunaan campuran Calcium Hydroxide dengan pasta iodoform adalah sebagai berikut: ${ }^{2}$

\section{A. Keuntungan:}

1. Merupakan bahan pengisi saluran akar geligi desidui yang paling mendekati ideal.

2. Perawatan berhasil baik pada gigi dengan kondisi tidak ada rasa sakit, tidak ada kegoyangan gigi yang bersifat patologis, gingiva sehat dan tidak ada fistel.

3. Pada kasus dengan radiolusensi pada daerah periapikal, pengisian saluran akar dengan bahan ini tampak dapat mengurangi ukuran radiolusensi tersebut dan menghasilkan regenerasi tulang di daerah yang terinfeksi pada pemeriksaan lebih lanjut.

4. Tidak sekeras pasta Zinc Oxide Eugenol sehingga tidak mengakibatkan gangguan/ kerusakan pada benih geligi permanen pengganti.

5. Mudah diambil bila diperlukan perawatan ulang.
6. Dapat diresorbsi dari jaringan apikal dalam waktu 1 minggu sampai 2 bulan.

7. Mudah diaplikasikan.

8. Bersifat antiseptik.

9. Perlekatan pada dinding saluran akar baik.

10. Bersifat radiopaque.

11. Tidak menyebabkan diskolorasi pada gigi yang dirawat.

\section{B. Kerugian:}

1. Harga bahan relatif mahal.

2. Tidak dapat menutup permukaan fraktur pada kasus injuri traumatik pada gigi vital.

Dari penelitian dan analisa hasil yang telah dilakukan didapatkan bahwa pengisian saluran akar geligi desidui dengan bahan Zinc Oxide Eugenol dan campuran $\mathrm{Ca}(\mathrm{OH})_{2}$ dengan pasta iodoform memiliki tingkat keberhasilan yang tidak jauh berbeda. Hasil ini sesuai dengan hasil penelitian yang dilakukan oleh Shani dkk (2000). ${ }^{6}$ Selain itu, dari penelitian yang dilakukan oleh Mortazavi dan Mesbahi (2004) juga dinyatakan bahwa perawatan saluran akar pada geligi desidui yang nekrosis baik dengan bahan pengisian Zinc Oxide Eugenol, maupun campuran Calcium Hydroxide dengan pasta iodoform merupakan prosedur yang berhasil. $^{2}$

Berdasarkan hasil uji statistik untuk kategori adanya rasa nyeri pada perkusi, didapatkan hasil bahwa baik bahan Zinc Oxide Eugenol maupun campuran Calcium Hydroxide dengan pasta iodoform memiliki efektifitas yang tidak jauh berbeda. Hal ini disebabkan karena kedua bahan tersebut memiliki efek analgesik. Pada Zinc Oxide Eugenol, efek analgesik berada pada eugenol yang mengandung sari minyak cengkeh, dimana sari minyak cengkeh itu menghasilkan efek sedatif dan anestesi lokal sehingga dapat mengurangi rasa nyeri. ${ }^{910,11}$ Sedangkan pada campuran Calcium Hydroxide dan pasta iodoform, efek analgesiknya dihasilkan akibat adanya reaksi Calcium Hydroxide dengan $\mathrm{CO}_{2}$ dari udara sehingga membentuk kalsium karbonat sebagai penghambat rasa nyeri. ${ }^{12}$ Pada kategori adanya fistel, terlihat adanya perbedaan kecepatan penyembuhan antara 2 kelompok uji, dimana tampak pada kelompok uji bahan campuran Calcium Hydroxide dengan pasta iodoform mengalami penyembuhan lebih cepat daripada kelompok uji Zinc Oxide Eugenol walaupun tidak bermakna. Hal itu terjadi karena Calcium Hydroxide memiliki sifat bakerisidal dimana konsentrasi ion hidroksil yang tinggi dapat membunuh mikroorganisme dalam saluran akar yang tidak terjangkau oleh instrumentasi dan irigasi. ${ }^{13}$ Pada prosesnya, ion hidroksil akan 
mendenaturasi protein dan menghidrolisis lemak pada lipopolisakarida (LPS) makrofag sehingga dapat mengaktivasi aktifitas biologis LPS seperti pirogenitas, toksisitas, aktivasi makrofag dan komplemen sehingga merusak dinding sel dan mengakibatkan kematian bakteri. ${ }^{14,15}$ Sementara itu, Zinc Oxide Eugenol walaupun bersifat bakteriosid $^{16}$ namun hanya memiliki spektrum antibakteri yang sempit, sehingga menghasilkan penyembuhan yang lebih lambat dan terbatas bila dibandingkan dengan campuran Calcium Hydroxide dan pasta iodoform. ${ }^{2,17}$

Selanjutnya pada kategori adanya bengkak intra oral juga terlihat bahwa kelompok uji campuran Calcium Hydroxide dengan pasta iodoform mengalami penyembuhan lebih cepat daripada kelompok uji Zinc Oxide Eugenol walaupun tidak bermakna. Hal itu disebabkan karena Calcium Hydroxide memiliki efek menghambat fagositas makrofag sehigga dapat menurunkan reaksi inflamasi. ${ }^{18}$

Pada penelitian ini, pemeriksaan rontgen difokuskan untuk melihat adanya radiolusensi periapikal. Dari hasil penelitian terlihat bahwa ukuran radiolusensi periapikal pada kelompok uji campuran Calcium Hydroxide dengan pasta iodoform mengalami ukuran lebih cepat daripada kelompok uji Zinc Oxide Eugenol walaupun tidak bermakna. Hal ini berkaitan dengan penjelasan pada kategori fistel. Selain itu, Calcium Hydroxide juga memiliki kemampuan melarutkan jaringan nekrotik, baik dalam lingkungan aerob maupun anaerob karena Calcium Hydroxide memiliki kemampuan untuk mendenaturasi protein dan menghidrolisis jaringan nekrotik akibat adanya ion hidroksil sehingga jaringan-jaringan nekrotik tersebut larut bila diirigasi dengan Natrium Hipoclorite. ${ }^{14,15}$

Bila dilihat dari segi sifat biologis bahan, Calcium Hydroxide bersifat basa karena mengandung ion hidroksil sementara eugenol yang terkandung dalam Zinc Oxide Eugenol bersifat asam. Seperti yang telah kita ketahui, apabila terjadi keradangan maka jaringan yang mengalami radang akan berada dalam suasana asam akibat adanya aktivitas komponen-komponen penyebab radang. Bila suatu keradangan diterapi dengan Calcium Hydroxide, maka ion hidroksil dari Calcium Hydroxide akan menetralkan suasana asam dari keradangan sehingga proses penyembuhannya dapat berlangsung lebih cepat. Sedangkan bila keradangan diterapi dengan Zinc Oxide Eugenol, maka suasana asam keradangan akan tetap asam atau malah menjadi lebih asam, sehingga proses penyembuhan menjadi lebih lambat atau malah menjadi lebih parah.

Kemudian untuk kategori terakhir yaitu adanya keluhan saat visit, terlihat bahwa keluhan lebih cepat berkurang pada kelompok uji campuran Calcium Hydroxide dengan pasta iodoform daripada kelompok uji Zinc Oxide Eugenol walaupun tidak bermakna. Hal ini berkaitan dengan penjelasan kategori-kategori lainnya, dimana terlihat campuran Calcium Hydroxide dengan pasta iodoform memiliki beberapa keunggulan dibandingkan dengan Zinc Oxide Eugenol walaupun secara statistik tidak bermakna.

\section{SIMPULAN DAN SARAN}

Dari penelitian ini dapat disimpulkan bahwa sediaan campuran Calcium Hydroxide dengan pasta iodoform maupun Zinc Oxide Eugenol merupakan bahan-bahan yang memiliki potensi baik sebagai bahan pengisi saluran akar gigi desidui dengan diagnosa nekrosis pulpa, namun sediaan campuran Calcium Hydroxide dengan pasta iodoform memiliki kemampuan untuk menyembuhkan keradangan periapikal lebih cepat bila dibandingkan dengan sediaan Zinc Oxide Eugenol walaupun secara statistik tidak menunjukkan perbedaan yang bermakna. Untuk selanjutnya peneliti menganggap perlu diadakan penelitian lebih lanjut dengan jumlah sampel yang lebih banyak dan rentang masa penelitian yang lebih panjang untuk dapat lebih memastikan tingkat keberhasilan dan juga dapat meneliti faktor-faktor lain dalam membandingkan tingkat keberhasilan campuran Calcium Hydroxide dengan pasta iodoform dan Zinc Oxide Eugenol sebagai bahan pengisi saluran akar geligi desidui.

\section{DAFTAR PUSTAKA}

1. Finn SB. Clinical Pedodontics. $4^{\text {th }}$ ed. Philadelphia: W.B. Saunders Company; 1973. p. 201-23.

2. Mortazavi M, Mesbahi M. Comparison of Zinc Oxide Eugenol, and Vitapex for Root Canal Treatment of Necrotic Primary Teeth. International Journal of Paediatric Dentistry 2004; 14: 417-24.

3. Nurko C, Gracia-Godoy F. Evaluation of Calcium Hydroxide/Iodoform Paste (Vitapex) in Root Canal Therapy for Primary Teeth. The Journal of Clinical Paediatric Dentistry. 1999; 23(4): 289- 94.

4. Kubota K, Golden BE, Penugonda B. Root Cannal Filling Materials for Primary Teeth: A Review of The Literature. Journal of Dentistry For Children 1992; Mei-June: 225-27.

5. Fuks AB. Pulp Therapy for The Primary Dentition. In: Pinkham JR, Casamassimo PS, McTigue DJ, Field HW, Nowak AJ, Editors. Pediatric Dentistry Infancy Through Adolescence. $4^{\text {th }}$ ed. China: Elseiver Saunders; 2005. p. 37581, 387-91.

6. Mani SA, Chawla HS. Evaluation of Calcium Hydroxide and Zinc Oxide Eugenol as Root Canal Filling Material in Primary Teeth. Journal of Dentistry For Children 2000; March-April: 142- 47.

7. Schröder U. Pedodontic Endodontic. In: Koch S, Poulsen S, Editors. Paediatric Dentistry. A Clinical Approach. $1^{\text {st }}$ ed. Munksgard: Copenhagen: The C.V. Mosby Company; 2001. p. 155-80.

8. Chawla HS, Mathur VP, Gauba K, Goyal A, Chandigargh. A Mixture of $\mathrm{Ca}(\mathrm{OH})_{2}$ Paste and $\mathrm{ZnO}$ powder as a Root 
Canal Filling Material for Primary Teeth. The Indian Social Preventif Pedodontics Dentistry 2001; September: 107- 09.

9. Yagiela JA, Dowd FJ, Neidle EA. Pharmacology \& Therapeutics for Dentistry. $5^{\text {th }}$ ed. Elsevier Mosby. p. 758.

10. Schunack W. Mayer K. Haake M. Arznestoffe, lehrbuch der pharmazeutischen cheime: Senyawa obat, Buku pelajaran kimia farmasi. Alih bahasa: Wattimena JR dan Soebito. Edisi 2. Jogjakarta: Gajah Mada University Press; 1990. h. 250, 456 .

11. British Pharma Copoeia. London: The Pharmaceutical Press; 1993. p. 69.

12. Soegijanto. Pengaruh kalsium hidroksida untuk mengurangi rasa nyeri dentin terbuka di servikal gigi. Majalah Kedokteran Gigi FKG Universitas Airlangga 1998; 31: 387-90.

13. Nerwich A, Figdor D, Messer HH. pH Changes in root dentin over a 4-week period following root canal dressing with calcium hydroxide. Journal Endodontic 1993; 19: 302-05.

14. Cohen S, Burns RC. Pathway of the Pulp. $7^{\text {th }}$ ed. St. Louis: CV. Mosby.Co; 1998. p. 43-4, 508-09 564-66.
15. Hasselgren G. Olsson B. Cvek M. Effect of calcium hydroxide and sodium hypoclorite on the dissolution of necrotic porcine muscle tissue. Journal Endodontic 1998; 14: 125-7.

16. Savioli RN, Pecora JD, Mian H, Ito IY. Evaluation of the antimicrobial activity of each component in Grossman's sealer. Brazillian Oral Restorative Journal 2006; 20(2):127-31.

17. Parfitt. Martindale: The Complete Drug Reference. $32^{\text {nd }} e d$. Massachusetts. The Pharmaceutical Press; 1999. p. 235-44. 302-3.

18. Segura, Juan José et al,Calcium hydroxide inhibits substrate adherence capacity of macrophages, Journal of Endodontics, Volume 3, Issue 7, 1997, p.444 - 447

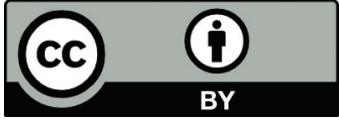

This work is licensed under a Creative Commons Attribution 